\title{
EXPLORING THE COMPLEMENTARITY BETWEEN FOREIGN TECHNOLOGY, EMBEDDED TECHNOLOGY AND INCREASE OF PRODUCTIVE CAPACITY
}

\author{
Jennifer GONZÁLEZ-BLANCOํ, Mercedes VILA-ALONSO², \\ Manuel GUISADO-GONZÁLEZ ${ }^{3 *}$ \\ ${ }^{1}$ Faculty of Economics and Business, University of Vigo, 36310 Vigo, Spain \\ ${ }^{2}$ Departament of Business Administration, University of Vigo, 36310 Vigo, Spain \\ ${ }^{3}$ Department of Financial Economics and Accounting, University of Extremadura, \\ Av. De la Universidad, 10071 Cáceres, Spain
}

Received 10 September 2017; accepted 28 October 2018

\begin{abstract}
This study analyzes the complementarity of foreign technology acquired under license agreements, technology embedded in machinery and equipment and increase in a company's productive capacity. We use panel data on Brazilian manufacturing companies from the World Bank Surveys. We used the random effects models, estimated by maximum likelihood. The results indicate that foreign technology, embedded technology and increase of productive capacity have a positive and significant impact on labor productivity. The complementarity test reveals that the relationship between the two technologies analyzed is conditionally substitutive and that the relationship between each of these technologies and increase of productive capacity is conditionally complementary.
\end{abstract}

Keywords: foreign technology, embedded technology, productive capacity, productivity, complementarity approach.

JEL Classification: C33, L60, O14, O32, O40.

\section{Introduction}

The technology gap approach argues that there exists a close relation between the level of economic development and the level of technological development (Fagerberg, 1987). In this context, technology is considered as the causal key that allows the efficient transformation of inputs into outputs, which makes it the most significant factor in improving productivity, quality, and competitiveness (Dahlman, 2007).

The successful experience of transition from underdevelopment to the development of many countries can be a valuable lesson for other countries that are pursuing a rapid evolu-

*Corresponding author. E-mail: manuelguisado@unex.es

This is an Open Access article distributed under the terms of the Creative Commons Attribution License (http://creativecommons. org/licenses/by/4.0/), which permits unrestricted use, distribution, and reproduction in any medium, provided the original author and source are credited. 
tion towards the industrialization of their economies (Kagami, 1995). And one of the key factors in this rapid industrialization has been the massive acquisition of technology from abroad (Tsurumi, 1984). In this regard, some empirical research shows that technology transferred from abroad has positive effects on developing countries (e.g., Buckley, Clegg, \& Wang, 2002).

Therefore, it should be stressed that one of the key problems for developing countries is the transfer of foreign technology (Attaran, Mehrmanesh, \& Jafarieh, 2014). However, there are different channels of technology transfer, so the success or failure of such transfer depends largely on the channel used. Likewise, the selected channel must simultaneously satisfy the transferor and the receiver expectations (Al-Ali, 1995).

As the interests and expectations of the receiving countries can be very different, and their capacities of absorbing and assimilating the transferred technology also vary, the transfer of technology can take many forms (Autio \& Laamanen, 1995). In this study we focus on the foreign technology acquired under license agreements and the technology embedded in machinery and equipment, since these two forms of transfer are the only ones available in the database that we manage and both constitute two of the most used forms of transfer. Thus, Olukoshi (1990) points out that the purchase of machinery and equipment constitutes the classic example of embodied technology transfer; Likewise, other studies also suggest that imports of machinery and equipment constitute an important channel to acquire advanced technology and improve the competitiveness of companies (Coe \& Helpman, 1995; Freeman $\&$ Soete, 1997). On the other hand, Kaynak (1985) indicates that the license agreements are the most versatile mechanism for transferring technology and that this type of transfer channel allows easy adaptation to the needs of the recipient country, through the corresponding negotiation with the licensor. Likewise, Caves (1982) points out that when host government policies hinder the execution of foreign direct investment, the preferred and most used channel of foreign technology transfer is the license agreements.

In general, the literature on growth indicates that industrial development constitutes an important basis for economic growth. Revenues generated in the industry have an important impact on the development of many other sectors, mainly in construction and services (Kaldor, 1960). The contributions of Kaldor (1960) indicate the existence of empirical regularities. These regularities can be synthesized in the following three laws (Cantore, Clara, \& Soare, 2017):

1) The manufacturing sector is the engine of GDP growth.

2) Productivity growth of the manufacturing sector is positively related to the growth of the manufacturing sector's output.

3) Productivity growth of the non-manufacturing sector is positively related to the growth of the manufacturing sector's output".

In the same vein, the Office of Business and Industrial Analysis (1995) indicates that "in all of the industrially advanced countries before 1960, and in the newly industrial countries of the post-1960 period, the development of indigenous manufacturing capability has been an invariable complement of rapidly increasing output growth".

From the contributions of Kaldor (1960) an extensive empirical literature has emerged trying to confirm or refute the validity of the first Kaldor law. In general, most of these 
empirical studies confirm it. Specifically, focused on different Latin American countries, the studies of Acevedo, Mold, \& Pérez Caldentey (2009) and Labanio and Moro (2011) find support to the first Kaldor law.

Therefore, in line with the arguments outlined above, it should be underlined that developing countries can have access to a broad and sustained economic growth through the transfer of foreign technology to their corresponding manufacturing sector. Consequently, this study analyzes the influence of the foreign technology acquired under a license agreement and embedded technology in the purchase of machinery and equipment on the labor productivity of manufacturing companies, using data from Brazilian manufacturing companies $^{1}$. Previous studies have analyzed the individual impact of each type of technology on business productivity. But, the impact on productivity that results from the simultaneous implementation of these variables has never previously been studied. In this study, the existence of complementarity / substitutability between both types of technology is analyzed. The econometric model we use to establish the relationship between technology and productivity is based on the foundations of the experience curve ${ }^{2}$ (Boston Consulting Group, 1972).

The postulates of the experience curve emphasize that there are two main sources of productivity for companies: on the one hand, technology, to the extent that technological innovations allow for achieving higher levels of efficiency; on the other, the growth of production, which facilitates the exploitation of economies of scale associated with technology (Buzzell, Gale, \& Sultan, 1975; Dosi, 1988).

In relation to the influence of technological innovation on productivity, there is abundant empirical literature. In general, virtually all studies have found that such influence is positive and significant (e.g., Griliches, 1986; Cassiman, Golovko, \& Martínez-Ros, 2010). However, most of these studies show a double bias: on the one hand, they have focused on the classic typological figures of innovation, such as product innovation, process innovation, radical innovation and incremental innovation; on the other, these analyses have focused on the productive apparatus of developed countries. Another notable flaw of these studies is that they have hardly explored the complementarity that results from the simultaneous implementation of two or more different types of technology (Guisado-González, Wright, \& Guisado-Tato, 2017a).

However, in our view, the greatest flaw lies in the absence of studies that have explored the potential complementarity between technology and growth, the two sources of productivity emphasized by the experience curve. If the simultaneous implementation of technology and growth achieves higher levels of productivity than the sum of their separate implementations, then companies and governments have an extraordinarily useful tool with which to increase business productivity and thereby the welfare and wealth of their citizens.

\footnotetext{
${ }^{1}$ In this study, the use of data from manufacturing companies is not only determined by the importance that the manufacturing sector has in the development of the economies of the countries according to the forecasts of the first law of Kaldor, but also because the transfer of technology through licensing agreements and purchase of machinery and equipment occurs mainly in the manufacturing sector.

${ }^{2}$ Most of the studies that analyze the determinants of productivity use the classic Cobb-Douglas production function, in which capital and labor are related to productivity. When studies go down to the scope of the company, many authors have introduced into the production function the variable innovation as a key determinant of productivity. In this sense, the experience curve model is no more than a variant of the classic Cobb-Douglas production function (Day \& Montgomery, 1983).
} 
This study aims to respond to the shortcomings previously outlined. And it does so by way of the following contributions. First, this study analyzes the impact on productivity of two extremely important types of technology: foreign technology acquired under a license agreement and embedded technology in the purchase of machinery and equipment. Both technologies play a very important role in the development of the productive apparatus of those countries that exhibit a precarious capacity for internally generating their own technology, which creates the need to import foreign technology and to buy machinery and equipment in order to increase their corresponding level of competitiveness (Bajo \& Díaz, 2002). There are few empirical studies that have considered the role that foreign technology plays in the productivity of companies, and even fewer which examine the influence of embedded technology in machinery and equipment.

Second, the two technologies mentioned above play an extremely important role in the dynamization of the so-called developing countries since, in general, these technologies are easily accessible. Therefore, the empirical analysis of this study focuses on the manufacturing sector of the Brazilian economy. In this way, we help to focus attention on the problems and opportunities of developing countries.

Third, most studies in this topic area have analyzed the individual impact of each type of technology on business productivity. But simultaneous implementation of different types of technology may result in higher/lower productivity than the sum of their independent implementations. This knowledge is crucial because it will help us to avoid technological combinations that are detrimental and to discover those that are beneficial. This analysis is carried out through the use of the so-called complementarity approach (Milgrom \& Roberts, 1990), an approach used with increasing frequency in empirical economic studies (e.g., Ballot, Fakhfakh, Galia, \& Salter, 2015; Guisado-González, González-Blanco, \& CocaPérez, 2017b). In addition, it should be stressed that analysis of the complementarity between foreign technology and embedded technology has never previously been carried out.

Fourth, finally, it must be emphasized that in this study we also use the complementarity approach to analyze the influence on productivity of the simultaneous interaction of foreign technology and growth, on the one hand, and embedded technology and growth on the other. The impact on productivity that results from the simultaneous implementation of these variables has never previously been studied. However, understanding this impact is crucial, especially for developing countries. If synergistic effects on productivity are derived from the simultaneous implementation of growth and technology, companies and governments have a clear guiding vision for the design of their respective policies to improve competitiveness.

In order to respond to the proposed objectives, this study is divided into the following sections. In the next section, we establish the theoretical framework and propose the corresponding hypotheses. Next, we describe the source of the data being used, define the variables and detail the methodology employed. In the two sections that follow, we discuss the results and present the conclusions. 


\section{Theoretical framework and hypotheses}

The experience curve indicates that the higher the cumulative production (experience) of a homogeneous product, the lower its unit cost of production will be. The causes of this reduction of costs lie in the efficiency of the technology and in the exploitation of the economies of scale and in the learning that the increase in production propitiates. From the model of the experience curve it is possible to find a relationship between productivity, experience and technology. The usual form of the experience curve is:

$$
C_{n}=C_{1} n^{-\lambda},
$$

where: $C_{n}$ - cost of the nth unit; $C_{1}$ - cost of the first unit; $n$ - cumulative number of units; $\lambda$ - elasticity of unit costs with respect to cumulative volume.

We consider a period in which " $q$ " units of a product were manufactured. We also consider the unit cost at the beginning of the period to be $C_{n}$ and at end of the period as $C_{n+q}$. In this period the growth rate of cumulative production $(\rho)$ and the rate of reduction of unit costs $(\mu)$ will be:

$$
\begin{gathered}
\rho=\frac{(n+q)-n}{n}=\frac{q}{n} ; \\
\mu=\frac{C_{n}-C_{n+q}}{C_{n}} .
\end{gathered}
$$

By combining expressions (1), (2) and (3), we obtain:

$$
\mu=1-(1+\rho)^{-\lambda} \text {. }
$$

Equation (4) reveals that there are two key sources of reducing unit costs (productivity): on the one hand, the growth rate of the experience $(\rho)$; on the other hand, the level of technological innovation, as represented by the coefficient $\lambda$. When the technology is more efficient, the slope of the respective experience curve is greater, and thus will also result in the largest reduction in unit costs. As a result, each technology will lead to a specific experience curve.

Thus, the model of the experience curve establishes a positive relationship among technology, experience and productivity.

With regard to the influence of technology on productivity, there is abundant literature. In general, most studies have found strong empirical evidence for the existence of a positive and significant influence (e.g., Mairesse, Mohnen, \& Kremp, 2005; Siedschlag, Zhang, \& Cahill, 2010). However, not all types of technological innovation have equal influence (Hall, 2011; Mohnen \& Hall, 2013). In the database that we use in this study we investigate two types of technology: on the one hand, the foreign technology used under license agreements; on the other, the technology embedded in machinery and equipment. The influence of both technologies on the productivity of companies has been scarcely studied empirically, despite the enormous importance that these two types of technology have in the productive structure of the developing countries.

In relation to foreign technology, there is evidence that its influence on productivity in developing countries is positive and significant (Coe, Helpman, \& Hoffmaister, 1997; Falvey, Foster, \& Greenaway, 2004). On the other hand, on the technology embedded in machinery 
and equipment the existing empirical literature is very scarce. Among the small number of works addressing that question, Geroski (1991) finds that embedded technologies have a positive and significant impact on productivity growth, while Romer (1990) and Griliches (1998) have found evidence that investments in machinery and equipment positively influence the innovative performance of companies. Taking into account these indications, we propose the following hypotheses:

H1. In the Brazilian manufacturing sector, foreign technology acquired under license has a positive and significant influence on the productivity of companies.

H2. In the Brazilian manufacturing sector, the technology embedded in machinery and equipment has a positive and significant influence on the productivity of companies.

In relation to production capacity, Wright (1936) was the first author to suggest a direct relationship between cumulative production increases and productivity. Subsequently, Rapping (1965) and Hollander (1965) confirmed this relationship. In addition, the Boston Consulting Group (1972) was the first to undertake a mass study on a large number of products, confirming that the growth rate of experience has a positive influence on business productivity. The relationship between experience and productivity has again been confirmed by many other studies in different types of firms (e.g., Stobaugh \& Townsend, 1975; Dutton, Thomas, \& Butler, 1984; Darr, Argote, \& Epple, 1995). In line with the cited literature, we propose the following hypothesis:

H3. In the Brazilian manufacturing sector, the increase in productive capacity has a positive and significant influence on the productivity of companies.

However, in relation to technological innovation, it should be noted that there are different types, and thus their effects on productivity may depend on whether these different types act independently or jointly (Mohnen \& Hall, 2013). In this sense, authors like Damanpour and Gopalakrishnam (2001) have argued that each type of innovation can only be understood in terms of mutual interdependence. Consequently, a relationship of either complementarity or substitutability is expected between the different types of innovation, i.e. the impact on the productivity of the simultaneous implementation of two different types of innovation may be higher or lower than the sum of their separate implementations.

In line with the above, another objective of this study is to analyze whether the relationship between foreign technology and embedded technology is complementary or substitutive. We also analyze the relationship between increase in productive capacity and the two types of innovation considered in this study.

The field of innovation is where the greatest number studies of complementarity have been made. The results obtained, in general, have not been conclusive. For example, on the relationship between the internal innovation strategy and the external innovation strategy, some studies have found significant evidence of complementarity (e.g., Cassiman \& Veugelers, 2006; Lokshin, Belderbos, \& Carree, 2008; Cruz-Cázares, Bayona-Sáez, \& García-Marco, 2010), but others have found evidence of substitutability (e.g., Laursen \& Salter, 2006; VegaJurado, Gutiérrez-Gracia, \& Fernández de Lucio, 2009; Jirjahn \& Kraft, 2011).

At the same time, in the area of product, process and organizational innovations, there are no conclusive results either. For example, Vega-Jurado et al. (2009) have found evidence of 
complementarity between product and process innovations, while other studies have found both complementary and non-related effects (Ballot et al., 2015; Guisado-González et al., 2017a).

In general, the literature on innovation stresses that the achievement of complementarities depends not only on the combination of policies that seem appropriate at first, but also on the absence or presence of other business policies (Cassiman \& Veugelers, 2006). In this sense, the literature emphasizes that the possession of powerful internal R \& D departments plays an important catalytic role in the emergence of complementarities between different technological inputs (Catozzella \& Vivarelli, 2014).

Therefore, the existence or non-existence of complementarity between foreign technology and embedded technology depends not only on the potential of these two types of innovation, but also on the level of resources and capabilities of enterprises. However, in general, the levels of technological resources and capabilities of enterprises in developing countries are often low, making it extremely difficult for these companies to absorb knowledge simultaneously from these two types of technology. Therefore, we propose the following hypothesis:

H4. In the Brazilian manufacturing sector, the relationship between foreign technology acquired under license and embedded technology in machinery and equipment is substitutive in relation to the labor productivity of firms.

Finally, in regard to the potential complementarity between the two technologies analyzed and increase in production capacity, it should be noted that no previous study has explored this kind of complementarity. However, there is an abundant literature that emphasizes that the companies which innovate and grow the most are those that achieve better economic results (e.g., Freel, 2000; Ahmad \& Petersen, 2007; Henrekson \& Johansson, 2008). That is, the companies that grow the most produce more and, therefore, manage to exploit the full potential of the economies of scale of the technologies they use. Therefore, in congruence with the literature, we propose the following hypotheses:

H5. In the Brazilian manufacturing sector, the relationship between the increase in productive capacity and foreign technology acquired under license is complementary in relation to the labor productivity of firms.

H6. In the Brazilian manufacturing sector, the relationship between the increase in productive capacity and embedded technology in machinery and equipment is complementary in relation to the labor productivity of firms.

\section{Data, variables and methodology}

\subsection{Data}

The data used are of Brazilian manufacturing companies and come from the Enterprise Surveys of the World Bank. The data are grouped in a panel database at company level, and are related to fiscal years 2002 and 2007. Surveys have been conducted during 2003 and 20082009 , respectively. This is the last panel of companies that the World Bank has on Brazil. The sample initially consists of 3,444 observations, including industrial and service companies. After selecting the manufacturing companies and purifying the sample, as a consequence of 
the presence of missing and atypical values in the variables of interest, we worked with a final sample of 2,416 observations. This is an unbalanced panel database, as it consists of 1,449 observations for fiscal year 2002 and 967 observations for fiscal year 2007.

The use of panel data allows us to obtain robust estimators, facilitating the overcoming of the problems caused by the unobservable heterogeneity present mainly in the cross-section data (Miravete \& Pernías, 2006).

\subsection{Variables}

In this study we used the logarithm of labor productivity as a dependent variable. Labor productivity is determined by dividing annual sales by the total number of workers in each company. Since we use panel data, the economic content variables of this study are expressed in constant monetary units, in order to prevent inflation from distorting the results.

In relation to innovation, the World Bank survey of Brazilian companies asked the following question $(0,1)$ : Does the company currently use licensed technology from foreign companies? (Foreign technology).

The acquisition of machinery and equipment constitutes the main source of technological knowledge for companies that belong to sectors that use traditional technology (Pavitt 1984; Bogliacino \& Pianta, 2015). The World Bank survey asks what is the book value of machinery and equipment that companies own. In this way, it is possible to construct a binary variable that reflects the degree of the technology embedded by the companies (Embedded technology), differentiating this degree of importance by sectors. Obviously, the different manufacturing sectors do not have the same technological intensity, so it seems reasonable to take the sector average rather than the average of the entire manufacturing field as a reference. In this regard, we calculate the average value of machinery and equipment of each Brazilian manufacturing sector. Companies that have an accounting value greater than or equal to the average of the corresponding sector are given the value 1 . Those with a value lower than the average of their sector are given the value 0 .

Regarding the utilization of productive capacity, the World Bank asked the Brazilian companies about the number of permanent jobs at the end of the year and the number of permanent jobs three years ago. Therefore, we can construct a binary variable that indirectly reflects the variation of the productive capacity of the companies (productive capacity): the companies that have reduced their workforce are given the value 0 ; those who have maintained or increased it are given the value 1 .

Finally, this study uses three variables that act as contextual and control variables, and whose relevant role is recognized by the literature on productivity and innovation.

Being part of a group of companies (Group) provides, in many cases, important advantages. In this respect, it is generally noted that these companies have privileged access to sources of finance and technology (Khanna \& Palepu, 2000), a greater probability of exploiting economies of scope (Henderson \& Cockburn, 1996) and access to internal information sources of the group that can improve their corresponding innovation capacities (Piga \& Vivarelli, 2004). Therefore, it is assumed that, in general, the companies belonging to a group are more likely to achieve better levels of productivity than the independent firms (Choo, Lee, Ryu, \& Yoon, 2009). 
Also, in general, companies that sell in international markets are subject to greater competitive pressure (Foster, Haltiwanger, \& Syverson, 2008; Suárez-Porto \& Guisado-González, 2014), since they have to satisfy a larger mosaic of heterogeneous and more complex needs. Therefore, in this study we use the export variable as a proxy variable of competitive pressure, as it reflects the percentage of exports in the company's turnover.

Larger enterprises have the greatest opportunities to exploit economies of scale, since they generally use more efficient technologies (experience curve with greater slope) and increase their experience at a higher rate as a consequence of their greater market share (Jovanovic, 1982). However, some studies have also pointed out that small firms are more innovative and flexible and can achieve higher levels of productivity for that reason (e.g., Hall, Lotti, \& Mairesse, 2009). In this study the size is represented by the logarithm of the total employment (fixed employment plus temporary employment) of each company.

Finally, as the levels of innovation and productivity differ substantially between sectors, it is necessary to control these asymmetries in the regression, so we include in the model as many dummy variables as manufacturing sectors exist in the World Bank survey.

\subsection{Methodology}

Formally, it is said that two activities are complementary if the sum of the benefits that result from the implementation of one or the other is less than the benefits that are obtained from their joint implementation.

To implement the complementarity approach proposed by Milgrom and Roberts (1990) it is necessary to define an objective function beforehand. Assuming that $X i$ and $X j$ are two activities and that $Z$ is a vector of exogenous variables in the function $F\left(X_{i}, X_{j}, Z\right)$, and considering that $X_{i}$ and $X_{j}$ are dichotomous variables that take the value 1 when they are adopted and the value 0 when they are not, the complementarity approach regresses the objective pursued on a unique combination of the two activities considered and on the vector of exogenous variables:

$$
F\left(X_{i}, X_{j}, Z\right)=\beta_{00}\left(1-X_{i}\right)\left(1-X_{j}\right)+\beta_{10} X_{i}\left(1-X_{j}\right)+\beta_{01}\left(1-X_{i}\right) X_{j}+\beta_{11} X_{i} X_{j}+\beta_{z} Z+e .
$$

$\beta_{11}$ measures the partial cross yields of choosing $X_{\mathrm{i}}$ and $X_{j}$ together; $\beta_{10}$ measures the yields of choosing only $X_{i} ; \beta_{01}$ measures the yields of choosing only $X_{j} ; \beta_{00}$ measures the yields derived from not choosing either activity.

Then, we can state that the objective function $F\left(X_{i}, X_{j}, Z\right)$ is supermodular and $X_{i}$ and $X_{j}$ are complementary if:

$$
\beta_{11}+\beta_{00}-\beta_{10}-\beta_{01}>0 \text {. }
$$

Obviously, the objective function $F\left(X_{i}, X_{j}, Z\right)$ is said to be submodular and $X_{i}$ and $X_{j}$ are substitutes if:

$$
\beta_{11}+\beta_{00}-\beta_{10}-\beta_{01}<0 .
$$

Basically complementary approach there are two slightly different ways to raise the multivariate one-sided hypotheses. On the one hand, Mohnen and Röller (2005) uses strictly complementarity hypothesis ( $H 0: R \beta>r$ vs $H 1: R \beta \leq r$ ) while Belderbos, Carree, and Lok- 
shin (2006) uses non-strictly complementarity hypothesis ( $H 0: R \beta=r H 1: R \beta \geq r$ ). Ballot et al. (2015) call the first test unconditional complementarities and the second conditional complementarities. However, since unconditional tests are often inconclusive (i.e., Leiponen, 2005; Love \& Roper, 2009; Doran, 2012), Ballot et al. (2015) propose to use the conditional complementarity test, since this is usually more conclusive, mainly when analyzing more than two variables, as it happens in this paper. Consequently, we focus on conditional tests as Ballot et al. (2015).

Obviously, the number of inequalities that will need to be contrasted will depend on the number of variables whose complementarity is sought. According to Topkis (1978), when there are $\mathrm{k}$ variables the number of non-trivial inequalities to be contrasted will be $2^{k-2} \sum_{i=1}^{k-1} i$. In this study, since there are three variables, the number of restrictions to be tested will be six, that is, two restrictions for each pair of variables. For example, if we want to contrast the complementarity between foreign technology and embedded technology, we must test the following two non-trivial inequalities:

$\beta_{110}+\beta_{000}-\beta_{100}-\beta_{010}>0$

(among companies that do not increase their productive capacity);

$\beta_{111}+\beta_{001}-\beta_{101}-\beta_{011}>0$

(among companies that increase their productive capacity).

In this study we use two random effects models. In model I we incorporate all the previously defined variables. The determination of the coefficients of these variables will allow us to test hypotheses 1, 2 and 3. In model II we substitute the variables foreign technology, embedded technology and production capacity by eight exclusive profiles of these three variables. For example, the variable ( $\left.\begin{array}{lll}1 & 1 & 0\end{array}\right)$ represents the unique combination of companies that use foreign technology and embedded technology, but have not increased their production capacity. The coefficients of the eight exclusive variables will be used to contrast hypotheses 4, 5 and 6.

To implement complementarity tests it is necessary to estimate the coefficients of all the dummies representing the eight possible exclusive combinations of the three variables of interest (foreign technology, embedded technology and productive capacity). But the presence in the model of the eight exclusive variables generates perfect multicolineality, so the model collapses and can't be estimated. Therefore, to avoid this perfect multicollinearity, it is necessary to eliminate the constant of the model. To estimate the model, we use the Stata software. For panel data and linear models, Stata provides five different model estimators. Three of these estimators (random-effects generalized least squares, between effects and fixed effects) do not allow to suppress the constant of the model.

In addition, these three estimators only use "within" variation for the data (variation in time for a given company). Therefore, with these estimators the regressors that do not vary with time can not be estimated. This feature prevents the formulation of models that incorporate time-invariant regressors. However, with the objective of controlling the great differences that exist between the different manufacturing industries, our model includes industry dummies at the two-digit industry classification level. These dummy variables are time invariant. 
Therefore, these three estimators cannot be used in our analysis, to the extent that they do not allow us to estimate all the coefficients of the eight exclusive variables and do not allow us to carry out a correct specification of our model. Then, they can not be used to estimate our model.

The other two panel data estimators that Stata offers (maximum likelihood random-effects and population-average) do not have any of the two previous limitations referenced: both allow to suppress the constant of the model and use both temporal variability (within) and inter-firm variability (between). In our analysis, the complementarity tests of these estimators (ML random-effects and population-average) provide the same results. We expose the corresponding data to the ML random-effects estimator.

\section{Results and discussion}

Table 1 shows the descriptive statistics of the variables used in this study. Of the three variables that are the subject of special attention, $7.5 \%$ of the companies in the sample exhibit a use of embedded technology superior to the average of their corresponding sector. Likewise, it is noted that $10.5 \%$ of companies use foreign technology under a license agreement. On the other hand, it is noteworthy that, during the period of analysis, 70.6\% of Brazilian manufacturing companies opted to increase their productive capacity.

In relation to the eight exclusive combinations of foreign technology, embedded technology and productive capacity, it can be seen that companies that increase their productive capacity, do not use foreign technology and do not have machinery and equipment above the average of their corresponding sector (embedded technology) constitute $58.6 \%$ of the

Table 1. Descriptive statistics

\begin{tabular}{|c|c|c|c|}
\hline & Nature of the variable & Mean & Standard deviation \\
\hline Labor productivity & Continuous & 5.210 & 0.981 \\
\hline Export & Continuous & 0.071 & 0.196 \\
\hline Size & Continuous & 1.698 & 0.533 \\
\hline Group & Binary $\left(\begin{array}{lll}0 & 1\end{array}\right)$ & 0.108 & 0.311 \\
\hline Foreign technology & Binary (lll) & 0.105 & 0.306 \\
\hline Embedded technology & Binary $\left(\begin{array}{ll}0 & 1\end{array}\right)$ & 0.075 & 0.262 \\
\hline Productive capacity & Binary (lll) & 0.706 & 0.455 \\
\hline$\left(\begin{array}{lll}0 & 0 & 0\end{array}\right)$ & Binary (lll) & 0.253 & 0.434 \\
\hline$\left(\begin{array}{lll}1 & 1 & 1\end{array}\right)$ & Binary $\left(\begin{array}{lll}0 & 1\end{array}\right)$ & 0.013 & 0.114 \\
\hline$\left(\begin{array}{lll}1 & 0 & 0\end{array}\right)^{*}$ & Binary $\left(\begin{array}{lll}0 & 1\end{array}\right)$ & 0.022 & 0.145 \\
\hline$\left(\begin{array}{lll}0 & 1 & 0\end{array}\right)^{\star \star *}$ & Binary $\left(\begin{array}{lll}0 & 1\end{array}\right)$ & 0.015 & 0.122 \\
\hline$\left(\begin{array}{lll}0 & 0 & 1\end{array}\right)^{\star * *}$ & Binary $\left(\begin{array}{lll}0 & 1\end{array}\right)$ & 0.586 & 0.492 \\
\hline$\left(\begin{array}{lll}1 & 1 & 0\end{array}\right)$ & Binary $\left(\begin{array}{ll}0 & 1\end{array}\right)$ & 0.005 & 0.067 \\
\hline$\left(\begin{array}{lll}1 & 0 & 1\end{array}\right)$ & Binary $\left(\begin{array}{ll}0 & 1\end{array}\right)$ & 0.065 & 0.247 \\
\hline$\left(\begin{array}{lll}0 & 1 & 1\end{array}\right)$ & Binary $\left(\begin{array}{lll}0 & 1\end{array}\right)$ & 0.041 & 0.199 \\
\hline
\end{tabular}

Notes: ${ }^{*}$ - only foreign technology; ${ }^{* *}$ - only embedded technology; ${ }^{* *}$ - only productive capacity. 
companies in the sample. Therefore, it seems evident that a majority of Brazilian companies seek to improve their productivity by increasing their productive capacity, with technological innovation occupying a much more secondary role. Thus, only $2.2 \%$ of companies rely exclusively on foreign technology as a source of productivity, while those that exclusively use a higher proportion of embedded technology than the corresponding sectoral average represent only a small $1.5 \%$.

Table 2 shows the estimated coefficients of the maximum-likelihood regression of the two random effects models used in this study. In model I we can see that the variables foreign technology, embedded technology and productive capacity have a positive and fully significant influence on the labor productivity of companies. Therefore, we confirm that hypotheses 1, 2 and 3 are fulfilled. This confirmation is in line with the results of the few tests that have been carried out on foreign technology (e.g., Falvey et al., 2004), embedded technology (e.g., Geroski, 1991) and increased productive capacity (e.g., Callejon \& Segarra, 1999). In quantitative terms, productive capacity is the one that has the lowest influence on productivity although, as we have already pointed out, it is the one that is followed mostly by Brazilian companies.

On the other hand, the estimated coefficients of model I also show that belonging to a group of companies and being an exporting company together have a positive and significant influence on a company's labor productivity. Likewise, size has a negative and fully significant

Table 2. Results of random effects models

\begin{tabular}{|c|c|c|c|c|}
\hline \multirow{2}{*}{$\begin{array}{l}\text { Dependent variable: } \\
\text { Labor productivity }\end{array}$} & \multicolumn{2}{|c|}{ Model I } & \multicolumn{2}{|c|}{ Model II } \\
\hline & Coefficient & Standard error & Coefficient & Standard error \\
\hline Export & $0.2941^{\star * *}$ & 0.08749 & $0.2838^{\star * *}$ & 0.08763 \\
\hline Size & $-0.1510^{\star * *}$ & 0.03446 & $-0.1457^{\star * *}$ & 0.03446 \\
\hline Group & $0.3286^{\star * *}$ & 0.05567 & $0.3214^{* * *}$ & 0.05564 \\
\hline Foreign technology & $0.3665^{\star * *}$ & 0.05490 & - & - \\
\hline Embedded technology & $1.6157^{\star * *}$ & 0.06390 & - & - \\
\hline Productive capacity & $0.1267^{\star * *}$ & 0.03527 & - & - \\
\hline$\left(\begin{array}{lll}0 & 0 & 0\end{array}\right)$ & - & - & $4.9260^{* * *}$ & 0.22568 \\
\hline$\left(\begin{array}{lll}1 & 1 & 1\end{array}\right)$ & - & - & $6.8778^{* * *}$ & 0.26961 \\
\hline$\left(\begin{array}{lll}1 & 0 & 0\end{array}\right)^{\star}$ & - & - & $5.4060^{* * *}$ & 0.24835 \\
\hline$\left(\begin{array}{lll}0 & 1 & 0\end{array}\right)^{* *}$ & - & - & $6.6990^{* * *}$ & 0.26192 \\
\hline$\left(\begin{array}{lll}0 & 0 & 1\end{array}\right)^{\star * *}$ & - & - & $5.0551^{* * *}$ & 0.22429 \\
\hline$\left(\begin{array}{lll}1 & 1 & 0\end{array}\right)$ & - & - & $6.3261^{\star * *}$ & 0.33311 \\
\hline$\left(\begin{array}{lll}1 & 0 & 1\end{array}\right)$ & - & - & $5.4681^{* * *}$ & 0.23460 \\
\hline$\left(\begin{array}{lll}0 & 1 & 1\end{array}\right)$ & - & - & $6.7385^{\star * \star}$ & 0.23505 \\
\hline Constant & $4.9591^{\star * *}$ & 0.22551 & - & - \\
\hline Sectoral dummies & \multicolumn{2}{|c|}{ Included } & \multicolumn{2}{|c|}{ Included } \\
\hline Model & \multicolumn{2}{|c|}{ LR chi2 $=1073.61^{\star * *}$} & \multicolumn{2}{|c|}{ Wald chi2 $=108065.94^{\star * *}$} \\
\hline
\end{tabular}

Statistical significance of the coefficients: ${ }^{* *}-1 \%$; ${ }^{*}-5 \%$ and ${ }^{\star}-10 \%$. 
statistical influence. Consequently, in the context of Brazilian manufacturing companies, the results tell us that it is the smaller companies that achieve better levels of productivity.

Finally, Table 3 shows the results of the complementarity tests performed from the estimated coefficients of the eight exclusive variables (model II). Complementarity is explored between pairs of variables. The relationship between each pair of variables is tested in two different scenarios, depending on whether or not the third unexamined variable is present in each test.

Thus, the first pair of variables tested is that of foreign technology and embedded technology. When the test is practiced among companies that have not increased their productive capacity during the analysis period, we find that the relationship between both variables is substitutive. If the test is performed with companies that have increased their productive capacity, it is verified that there is no relationship between the two types of technologies tested. Therefore, we can say that hypothesis 4 is partially fulfilled. This result is similar to that obtained by other authors who have tested the complementarity between different types of technologies. These authors have also obtained mixed results (e.g., Ballot et al., 2015, Guisado-González et al., 2017a).

Table 3. Complementary tests

\begin{tabular}{|c|c|c|c|}
\hline & & Chi2 & P-value \\
\hline \multirow{4}{*}{ 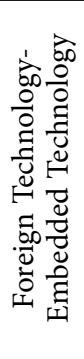 } & \multirow{2}{*}{$\begin{array}{l}\text { Productive capacity }=0 \\
\mathrm{~T} 1: \beta_{110}+\beta_{000}-\beta_{010}-\beta_{100}=0 \\
\mathrm{~T} 2: \beta_{110}+\beta_{000}-\beta_{010}-\beta_{100} \leq 0 \\
\text { Complementary / Substitutability / No relation }\end{array}$} & 8.48 & $\begin{array}{l}0.00 \\
0.99\end{array}$ \\
\hline & & \multicolumn{2}{|c|}{ Substitutive } \\
\hline & \multirow{2}{*}{$\begin{array}{l}\text { Productive capacity }=1 \\
\text { T1: } \beta_{111}+\beta_{001}-\beta_{011}-\beta_{101}=0 \\
\text { T2: } \beta_{111}+\beta_{001}-\beta_{011}-\beta_{101} \leq 0 \\
\text { Complementary / Substitutability / No relation }\end{array}$} & 2.50 & 0.11 \\
\hline & & \multicolumn{2}{|c|}{ No relation } \\
\hline \multirow{4}{*}{ 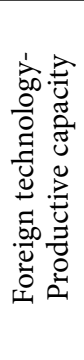 } & \multirow{2}{*}{$\begin{array}{l}\text { Embedded technology }=0 \\
\mathrm{~T} 1: \beta_{101}+\beta_{000}-\beta_{100}-\beta_{001}=0 \\
\mathrm{~T} 2: \beta_{101}+\beta_{000}-\beta_{100}-\beta_{001} \leq 0 \\
\text { Complementary / Substitutability / No relation }\end{array}$} & 0.26 & 0.61 \\
\hline & & \multicolumn{2}{|c|}{ No relation } \\
\hline & \multirow{2}{*}{$\begin{array}{l}\text { Embedded technology }=1 \\
\text { T1: } \beta_{111}+\beta_{010}-\beta_{110}-\beta_{011}=0 \\
\text { T2: } \beta_{111}+\beta_{010}-\beta_{110}-\beta_{011} \leq 0 \\
\text { Complementary / Substitutability / No relation }\end{array}$} & 2.67 & $\begin{array}{l}0.10 \\
0.05\end{array}$ \\
\hline & & \multicolumn{2}{|c|}{ Complementary } \\
\hline \multirow{4}{*}{ 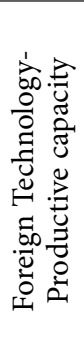 } & \multirow{2}{*}{$\begin{array}{l}\text { Foreign Technology }=0 \\
\text { T1: } \beta_{011}+\beta_{000}-\beta_{010}-\beta_{001}=0 \\
\text { T2: } \beta_{011}+\beta_{000}-\beta_{010}-\beta_{001} \leq 0 \\
\text { Complementary / Substitutability / No relation }\end{array}$} & 0.33 & 0.56 \\
\hline & & \multicolumn{2}{|c|}{ No relation } \\
\hline & \multirow{2}{*}{$\begin{array}{l}\text { Foreign Technology }=1 \\
\text { T1: } \beta_{111}+\beta_{100}-\beta_{110}-\beta_{101}=0 \\
\text { T2: } \beta_{111}+\beta_{100}-\beta_{110}-\beta_{101} \leq 0 \\
\text { Complementary / Substitutability / No relation }\end{array}$} & 2.63 & $\begin{array}{l}0.10 \\
0.05\end{array}$ \\
\hline & & \multicolumn{2}{|c|}{ Complementary } \\
\hline
\end{tabular}


The next pair of variables tested is foreign technology and increase of productive capacity. The test that is performed on companies that exhibit a stock of machinery and equipment below the average of the corresponding sector (where the embedded technology variable is zero) indicates that there is no relationship between the two variables. However, when the test is performed on the set of companies in which the variable embedded technology is 1 , the existence of complementarity is verified. That is to say, the complementarity between foreign technology and increase of productive capacity only takes place among the Brazilian manufacturing companies that exhibit a stock of machinery and equipment superior to the average of their corresponding sector, and not among all classes of manufacturing companies. Consequently, the possession of greater resources and capabilities (foreign technology and embedded technology, jointly) has positive and additional effects on productivity. Thus, the hypothesis tests indicate that the simple combination of foreign technology and growth is not enough to generate synergies, since this combination does not produce complementary effects in companies that exhibit a low level of embedded technology. Therefore, hypothesis 5 is partially fulfilled.

Finally, the test of complementarity between embedded technology and increase of productive capacity performed among companies that do not use foreign technology reveals that there is no relationship between the two variables analyzed. However, when the test is performed among companies that use foreign technology, there is evidence of complementarity. Therefore, the tests partially confirm hypothesis 6 .

Thus, the hypothesis tests carried out indicate that, in the context of the Brazilian economy, the combination of foreign technology, embedded technology and increased productive capacity can positively and significantly increase the productivity of companies through two channels: on the one hand, through that combination's direct and independent impact on productivity; on the other hand, through the additional increases in productivity generated by the joint implementation of the three variables. This finding is extremely important for all those countries that want to increase the development of their economies: the use of foreign technology and technology embedded in machinery and equipment, together with the simultaneous implementation of policies aimed at promoting economic growth, generates multiplicative effects on the productivity of the companies and, therefore, contributes to the increase of the welfare and wealth of the corresponding countries.

Table 4 summarizes the theoretical hypotheses raised and the corresponding empirical findings.

Table 4. Summary of hypothesis and empirical results

\begin{tabular}{|l|l|l|}
\hline \multicolumn{1}{|c|}{ Variable or combination of variables } & \multicolumn{1}{c|}{ Expected effect on productivity } & \multicolumn{1}{c|}{ Finding } \\
\hline Foreign technology & Positive and significant influence & Yes \\
\hline Embedded technology & Positive and significant influence & Yes \\
\hline Productive capacity & Positive and significant influence & Yes \\
\hline Foreign technology/Embedded technology & Substitutive & Yes, conditional \\
\hline Foreign technology/Productive capacity & Complementarity & Yes, conditional \\
\hline Embedded technology/Productive capacity & Complementarity & Yes, conditional \\
\hline
\end{tabular}




\section{Conclusions}

In this study we have explored the influence of the variables foreign technology, embedded technology and growth on the labor productivity of companies, using data from Brazilian manufacturing companies from the Enterprise Surveys of the World Bank. The empirical analysis has been carried out in two successive phases. The first has analyzed the individual impact of each of these variables on productivity. The second has evaluated how the joint implementation of these three variables increases or decreases their respective individual impacts on productivity. For the development of this second phase we have used the complementarity approach (Milgrom \& Roberts, 1990).

The results obtained in the first phase (model I) indicate that all three variables have a positive and significant influence on the labor productivity of companies. This finding is important, especially in terms of boosting the economies of developing countries, since these countries tend to have few capacities for the generation of their own technology, given their low levels of internal R\&D investment. Therefore, the development of policies aimed at attracting foreign technology and the purchase of machinery and equipment that incorporate high technological knowledge can contribute to the economic development of these countries.

Also, the results show that growth is a very important source of productivity, as predicted by the fundamentals of the experience curve. This finding is extremely relevant because it points out to policy makers and business managers that the implementation of growth policies is a solid path to economic development, since this variable has a direct and positive influence on productivity growth.

But the relevance that the growth of companies has on their corresponding productivity is much greater than that derived from their individual contribution. The complementary hypothesis tests developed from the estimates obtained in the second phase (model II) show that there is an additional increase of productivity when the variable growth moderates the relation of the two types of technologies analyzed, as well as when it interacts directly with both technologies.

Among companies that do not grow, the relationship of both technologies is substitutive, that is, the simultaneous implementation of foreign technology and embedded technology reduces the increase of productivity. When companies grow, the simultaneous implementation of both technologies is neutral, that is, there is no additional advantage or disadvantage on productivity. But where growth shows its full potential is when the two technologies are being implemented simultaneously, since the interaction of both technologies with growth is complementary, i.e., the joint implementation of technology and growth additionally increases productivity above the sum of their individual contributions. This finding is of extraordinary relevance as it reveals that companies that grow substantially and simultaneously implement foreign technology and embedded technology achieve higher productivity levels than companies that do not grow or do implement one or another technology separately.

Therefore, the findings of this study indicate that developing countries can achieve higher levels of productivity by designing and implementing policies aimed at promoting economic growth and the purchase of machinery and equipment with embedded technology, as well as creating the economic, social and institutional conditions that facilitate the capture of foreign 
technology, since the combination of greater resources and capabilities (foreign technology and embedded technology) and growth has complementary effects on the productivity of companies.

These findings have beneficial implications for business managers and policy makers, as both are concerned about achieving higher levels of productivity in their respective areas of responsibility.

From the macroeconomic point of view, the design and implementation of subsidy policies that favour the acquisition of machinery and equipment that incorporate high technologies will help to improve the resources and capacities of the companies and, therefore, their potential to achieve higher levels of productivity. Also, the design and implementation of policies that facilitate economic growth (e.g. reduced interest rates) will provide companies with higher levels of sales and, therefore, higher levels of productivity from two sources: on the one hand, greater production facilitates the exploitation of the economies of scale that the embedded technologies entail; on the other, it promotes the emergence of the complementarities that take place between technology and the increase of productive capacity.

From the business perspective, the same thing happens. Firms must boldly pursue a substantial improvement in their technological resources and capabilities, as well as seek to gain greater market shares in order to achieve higher rates of output growth. Both business policies (innovation and growth) have a direct impact on the productivity that companies achieve, an impact that is enhanced by the positive synergies (complementarities) that the simultaneous implementation of both policies entails.

In relation to this study it is necessary to point out a limitation from the available data and the approach used. There may be potential problems of endogeneity in our model. However, with the information provided by the database and with the application of the complementarity approach, it is not possible to control this potential endogeneity.

The database used does not provide additional technological data to those used in this study. Consequently, it is not possible to define and construct instrumental variables that substitute the technological variables used. Therefore, control of potential endogeneity by using the two-stage least-squares regression with instrumental variables is not possible.

On the other hand, in panel data models the GMM estimator is frequently used to control the potential endogeneity that could exist. However, this econometric technique can not be used in our study, since for the implementation of the complementarity test it is necessary to have previously estimated the coefficients of the eight exclusive variables. However, in the first differentiation the GMM estimator always eliminates one of the exclusive variables, so the complementarity test can not be implemented.

Therefore, it would be desirable for future research to use other databases that allow the definition and use of instrumental variables. These new studies will allow us to verify if the results obtained in our study are maintained.

\section{Funding}

The presentation of this work has been possible thanks to the funding granted by the European Regional Development Fund of the European Union and Junta de Extremadura to the research group DELSOS (Grant No. GR18095). 


\section{References}

Acevedo, A., Mold, A., \& Pérez Caldentey, E. (2009). The analysis of leading sectors: A long term view of 18 Latin American economies (MPRA Paper 15017). Germany: University Library of Munich.

Ahmad, N., \& Petersen, D. R. (2007). High-growth enterprises and gazelles - Preliminary and summary sensitivity analysis. Paris: OECD-FORA.

Al-Ali, S. (1995). Developing countries and technology transfer. International Journal of Technology Management, 10(7-8), 704-713.

Attaran, R., Mehrmanesh, H., \& Jafarieh, H. (2014). An ANP application for identifying and prioritizing opportunities and threatens for technology transfer, Decision Science Letters, 3, 85-92. https://doi.org/10.5267/j.dsl.2013.07.009

Autio, E., \& Laamanen, T. (1995). Measurement and evaluation of technology transfer: Review of technology transfer mechanisms and indicators. International Journal of Technology Management, 10(7-8), 643-664.

Bajo, O., \& Díaz, C. (2002). Inversión extranjera directa, innovación tecnológica y productividad. Una aplicación a la industria española. Economía Industrial, 347, 111-124.

Ballot, G., Fakhfakh, F., Galia, F., \& Salter, A. (2015). The fateful triangle. Complementarities between product, process and organizational innovation in the UK and France. Research Policy, 44(1), 217232. https://doi.org/10.1016/j.respol.2014.07.003

Belderbos, R., Carree, M., \& Lokshin, B. (2006). Complementarity in R\&D cooperation strategies. Review of Industrial Organization, 28(4), 401-426. https://doi.org/10.1007/s11151-006-9102-z

Bogliacino, F., \& Pianta, M. (2015). The Pavitt taxonomy, revisited. Patterns of innovation in manufacturing and services. Documentos de trabajo - Escuela de Economía 012631, UN - RCE - CID.

Boston Consulting Group. (1972). Perspectives on experience. Boston MA: The Boston Consulting Group.

Buckley, P., Clegg, J., \& Wang, C. (2002). The impact of inward FDI on the performance of Chinese manufacturing firms. Journal of International Business Studies, 38, 447-459. https://doi.org/10.1057/palgrave.jibs.8400274

Buzzell, R. D., Gale, B. T., \& Sultan, R. G. M. (1975). Market share: A key to profitability. Harvard Business Review, 53(1), 97-106.

Callejón, M., \& Segarra, A. (1999). Business dynamics and efficiency in industries and regions: The case of Spain. Small Business Economics, 13, 253-271. https://doi.org/10.1023/A:1008015317323

Cantore, N., Clara, M., \& Soare, C. (2017). Manufacturing as an engine of growth: Which is the best fuel?. Structural Change and Economic Dynamics, 42, 56-66. https://doi.org/10.1016/j.strueco.2017.04.004

Cassiman, B., \& Veugelers, R. (2006). In search of complementarity in innovation strategy: Internal $\mathrm{R} \& \mathrm{D}$ and external knowledge acquisition. Management Science, 52(1), 68-82. https://doi.org/10.1287/mnsc.1050.0470

Cassiman, B., Golovko, E., \& Martínez-Ros, E. (2010). Innovation, exports and productivity. International Journal of Industrial Organization, 28, 372-376. https://doi.org/10.1016/j.ijindorg.2010.03.005

Catozzella, A., \& Vivarelli, M. (2014). Beyond absorptive capacity: In-house R\&D as a driver of innovative complementarities. Applied Economics Letters, 21(1), 39-42. https://doi.org/10.1080/13504851.2013.835475

Caves, R. E. (1982). Multinational enterprise and economic analysis. Cambridge: Cambridge University Press.

Choo, K., Lee, K., Ryu, K., \& Yoon, J. (2009). Changing performance of business groups over two decades: technological capabilities and investment efficiency in Korean Chaebols. Economic Development and Cultural Change, 57(2), 359-386. https://doi.org/10.1086/592837 
Coe, D. T., \& Helpman, E. (1995). International R\&D spillovers. European Economic Review, 39, 859887. https://doi.org/10.1016/0014-2921(94)00100-E

Coe, D. T., Helpman, E., \& Hoffmaister, A. (1997) North-South R\&D spillovers. Economic Journal, 107, 134-149. https://doi.org/10.1111/1468-0297.00146

Cruz-Cázares, C., Bayona-Sáez, C., \& García-Marco, T. (2010). R\&D Strategies and firm innovative performance: A panel data analysis. International Journal of Innovation Management, 14(6), 1-33. https://doi.org/10.1142/S1363919610002982

Dahlman, C. (2007). Technology, globalization, and international competitiveness: Challenges for developing countries. In Industrial Development for the 21st Century: Sustainable Development Perspectives (pp. 29-83). Department of Economic and Social Affairs, United Nations, New York.

Damanpour, F., \& Gopalakrishnan, S. (2001). The dynamics of the adoption of product and process innovations in organizations. Journal of Management Studies, 38(1), 45-65.

https://doi.org/10.1111/1467-6486.00227

Darr, E., Argote, L., \& Epple, D. (1995). The acquisition, transfer, and depreciation of knowledge in service organizations: Productivity in franchises. Management Science, 41(11), 1750-1762. https://doi.org/10.1287/mnsc.41.11.1750

Day, G. S., \& Montgomery, D. B. (1983). Diagnosing the experience curve. Journal of Marketing, 47(2), 44-58. https://doi.org/10.1177/002224298304700205

Doran, J. (2012). Are differing forms of innovation complements or substitutes?. European Journal of Innovation Management, 15(3), 351-371. https://doi.org/10.1108/14601061211243675

Dosi, G. (1988). Sources, procedures and microeconomic effects of innovation. Journal of Economic Literature, 26(3), 1120-1171.

Dutton, J. M., Thomas, A., \& Butler, J. E. (1984). The history of progress functions as a managerial technology. Business History Review, 58(2), 204-233. https://doi.org/10.2307/3115048

Fagerberg, J. (1987). A technology gap approach to why growth rates differ. Research Policy, 16, 87-99. https://doi.org/10.1016/0048-7333(87)90025-4

Falvey, R., Foster, N., \& Greenaway, D. (2004). Imports, exports, knowledge spillovers and growth. Economics Letters, 85, 209-213. https://doi.org/10.1016/j.econlet.2004.04.007

Foster, L., Haltiwanger, J., \& Syverson, C. (2008). Reallocation, firm turnover, and efficiency: Selection on productivity or profitability?. American Economic Review 98(1), 394-425. https://doi.org/10.1257/aer.98.1.394

Freel, M. S. (2000). Do small innovating firms outperform non-innovators?. Small Business Economics, 14(3), 195-210. https://doi.org/10.1023/A:1008100206266

Freeman, C., \& Soete, L. (1997). The economics of industrial innovation. London: Pinter.

Geroski, P. A. (1991). Domestic and foreign entry in the United Kingdom: 1983-1984. In P. A. Geroski, J. Schwalbach (Eds.), Entry and market contestability: An international comparison. Oxford: Basil Blackwell.

Griliches, Z. (1986). Productivity, R\&D, and basic research at the firm level in the 1970's. American Economic Association, 76, 141-154.

Griliches, Z. (1998). R\&D and productivity: The econometric evidence. Chicago: The University of Chicago Press Books. https://doi.org/10.7208/chicago/9780226308906.001.0001

Guisado-González, M., González-Blanco, J., \& Coca-Pérez, J. L. (2017b). Analyzing the relationship between exploration, exploitation and organizational innovation. Journal of Knowledge Management, 21(5), 1142-1162. https://doi.org/10.1108/JKM-01-2017-0039

Guisado-González, M., Wright, L. T., \& Guisado-Tato, M. (2017a). Product-process matrix and complementarity approach. The Journal of Technology Transfer, 42(3), 441-459.

https://doi.org/10.1007/s10961-015-9435-6 
Hall, B. H. (2011). Innovation and productivity. Nordic Economic Policy Review, 2, 167-204. https://doi.org/10.3386/w17178

Hall, B. H., Lotti, F., \& Mairesse, J. (2009). Innovation and productivity in SMEs: Empirical evidence for Italy. Small Business Economics, 33, 13-33. https://doi.org/10.1007/s11187-009-9184-8

Henderson, R., \& Cockburn, I. (1996). Scale, scope, and spillovers: The determinants of research productivity in drug discovery. The Rand Journal of Economics, 27(1), 32-59.

Henkerson, M., \& Johansson, D. (2008). Gazelles as job creators - A survey and interpretation of the evidence (IFN working paper series, No. 733). Research Institute of Industrial Economics, Stockholm.

Hollander, S. (1965). The sources of increased efficiency: A study of DuPont Rayon Plants. Cambridge: M.I.T. Press.

Jirjahn, U., \& Kraft, K. (2011). Do spillovers stimulate incremental or drastic product innovations? Evidence from German stablishment data. Oxford Bulletin of Economics and Statistics, 73(4), 509538. https://doi.org/10.1111/j.1468-0084.2010.00618.x

Jovanovic, B. (1982). Selection and the evolution of industry. Econometrica, 50(3), 649-670. https://doi.org/10.2307/1912606

Kagami, M. (1995). The voice of East Asia: Development implication for Latin America. Tokyo: Institute of Developing Economies.

Kaldor, N. (1960). Causes of growth and stagnation in the world economy. Cambridge: Cambridge University Press.

Kaynak, E. (1985). Transfer of technology from developed to developing countries: some insights from Turkey. In A. Coskun Samli (Ed.), Technology transfer: Geographic, economic, cultural, and technical dimensions (pp. 155-176). Westport, Conn.: Quorum Books.

Khanna, T., \& Palepu, P. (2000). Is group affiliation profitable in emerging markets? An analysis of diversified Indian business groups. The Journal of Finance, 55(2), 867-891. https://doi.org/10.1111/0022-1082.00229

Labanio, G., \& Moro, S. (2011). Manufacturing industry and economic growth in Latin America: A kaldorian approach. In Proceedings of the 37th Brazilian Economics Meeting. Brazilian Association of Graduate Programs in Economics.

Laursen, K., \& Salter, A. (2006). Open for innovation: The role of openness in explaining innovation performance among U.K. manufacturing firms. Strategic Management Journal, 27(2), 131-150. https://doi.org/10.1002/smj.507

Leiponen, A. (2005). Skills and innovation. International Journal of Industrial Organization, 23(5-6), 303-323. https://doi.org/10.1016/j.ijindorg.2005.03.005

Lokshin, B., Belderbos, R., Carree, M. (2008). The productivity effects of internal and external R\&D: Evidence from a dynamic panel data model. Oxford Bulletin of Economics and Statistics, 70(3), 399413. https://doi.org/10.1111/j.1468-0084.2008.00503.x

Love, J. H., \& Roper, S. (1999). R\&D, technology transfer and networking effects on innovation intensity. Review of Industrial Organization, 15(1), 43-64. https://doi.org/10.1023/A:1007757110963

Mairesse, J., Mohnen, P., \& Kremp, E. (2005). The importance of R\&D and innovation for productivity: A reexamination in light of the 2000 French innovation survey. Annales d'Economie et de Statistique, 79-80, 489-529

Milgrom, P., \& Roberts, J. (1990). The economics of modern manufacturing: Technology, strategy, and organization. American Economic Review, 80, 511-528.

Miravete, E., \& Pernias, J. (2006). Innovation complementarity and scale of production. Journal of Industrial Economics, 54(1), 1-29. https://doi.org/10.1111/j.1467-6451.2006.00273.x

Mohnen, P., \& Hall, B. H. (2013). Innovation and productivity: An update. Eurasian Business Review, $3(1), 47-65$. 
Mohnen, P., \& Röller, L. H. (2005). Complementarities in innovation policy. European Economic Review, 49(6), 1431-1450. https://doi.org/10.1016/j.euroecorev.2003.12.003

Office of Business and Industrial Analysis. (1995). Engines of growth. Manufacturing industries in the U.S. economy. U.S. Department of Commerce.

Olukoshi, A. O. (1990). The dynamics of corporate technology transfer to Nigeria. In M. Chatterji (Ed.), Technology transfer in the developing countries. London: Macmillan. (pp. 364-374). https://doi.org/10.1007/978-1-349-20558-5_29

Pavitt, K. (1984). Sectoral patterns of technical change. Research Policy, 13, 343-373. https://doi.org/10.1016/0048-7333(84)90018-0

Piga, C., \& Vivarelli, M. (2004). Internal and external R\&D: A sample selection approach. Oxford Bulletin of Economics and Statistics, 66(4), 457-482. https://doi.org/10.1111/j.1468-0084.2004.00089.x

Rapping, L. (1965). Learning and World War II production functions. Review of Economics and Statistics, 47, 81-86. https://doi.org/10.2307/1924126

Romer, P. M. (1990). Endogenous technological change. Journal of Political Economy, 98, 71-102. https://doi.org/10.1086/261725

Siedschlag, I., Zhang, X., \& Cahill, B. (2010). The effects of the internationalization of firms on innovation and productivity (ESRI Working Paper).

Stobaugh, R. B., \& Townsend, P. L. (1975). Price forecasting and strategic planning: The case of petro chemicals. Journal of Marketing Research, 12, 19-29. https://doi.org/10.1177/002224377501200104

Suárez-Porto, V., \& Guisado-González, M. (2014). Analysis of the determinants of exporting intensity in the field of innovation. Investigaciones Europeas de Dirección y Economía de la Empresa, 20(2), 79-86. https://doi.org/10.1016/j.iedee.2013.12.002

Topkis, D. L. (1978). Minimizing a submodular function on a lattice. Operations Research, 26, 305-321. https://doi.org/10.1287/opre.26.2.305

Tsurumi, Y., \& Graham, E. M. (1984). Multinational management: Business strategy and government policy. Cambridge, MA: Ballinger Publishing.

Vega-Jurado, J., Gutiérrez-Gracia, A., \& Fernández de Lucio, I. (2009). La relación entre las estrategias de innovación: Coexistencia o complementariedad. Journal of Technology Management \& Innovation, 4(3), 74-88. https://doi.org/10.4067/S0718-27242009000300007

Wright, T. P. (1936). Factors affecting the cost of airplanes. Journal of the Aeronautical Sciences, 3(4), 122-128. https://doi.org/10.2514/8.155 